\title{
Landmark-based morphometric and meristic variations of Glossogobius giuris in three stocks
}

\author{
M. F. A. Mollah, S. Yeasmine, M. B. Hossen and A. K. S. Ahammad \\ Department of Fisheries Biology and Genetics, Bangladesh Agricultural University, Mymensingh-2202, Bangladesh. \\ E-mail: selina_bfri@yahoo.com
}

\begin{abstract}
Landmark-based morphometric and meristic analysis of pond, haor and estuary populations of Glossogobius giuris (Hamilton,1822) (Perciformes:Gobiidae) were done to find out variations among the three stocks. Samples were collected from three different regions such as pond of Mymensingh, haor of Kishoreganj and estuary of Barisal. Significant differences $\left({ }^{*} \mathrm{P}<0.01\right)$ were observed in 13 general morphometric and 23 size adjusted landmark-based morphometric measurements among three stocks. Among the 11 meristic counts the first dorsal fin rays (D1FR), transverse scale above lateral line (TSALL), branchiostegal rays and number of vertebrae were same among fishes of these stocks. In case of pectoral fin rays (PCFR) and transverse scale on lateral line (TSOLL) the haor stock was significantly different from other two stocks. In discriminant space, pond stock was isolated from other two stocks. On the other hand, haor and estuary stocks showed very close relationship. A dendrogram based on the hierarchical cluster analysis using size adjusted general morphometric and landmark measurements formed two main clusterspond stock in one cluster and other two stocks (haor and estuary) remained in another cluster. It indicates that pond stock was separated. The second cluster explained that haor and estuary stocks had very close relationship.
\end{abstract}

Keywords: Landmark-based, morphometric, meristic, variations, Glossogobius giuris

\section{Introduction}

One of the Small Indigenous Species (SIS), Glossogobius giuris, has a special preference in the diet of people of Bangladesh because of its unique taste, low fat and high protein content (Islam and Joadder, 2005). It is the only species of genus Glossogobius, available in Bangladesh (Rahman, 1989) locally known as baila or bele and a minor commercial species for capture fishery (Hoese, 1986). Glossogobius is a complex and diverse genus of gobiid fish predominantly available in the freshwater of Indo-west Pacific region. It commonly occurs in estuarine areas and freshwater throughout Bangladesh, Ceylon, India, Burma, Malaysia and Far East (Bhuiyan, 1964; Srivastava, 1968).

The feature that makes it a matter of special interest is its size variability. Body size variation of $G$. giuris in different region of Bangladesh is a typical fact. The largest fish has been found to reach a length of $40 \mathrm{~cm}$ (standard length) and the smallest about $3 \mathrm{~cm}$ (Hoese, 2008). Usually the individuals found in the confined waters like ponds are small and those collected from open water bodies like haors, rivers and estuaries are big. The possible explanation of this distinct size variability may include the preference and availability of food by the species as they are carnivorous and at the same time cannibalistic (Islam, 2002), influence of water quality and confined condition of some freshwater bodies (ponds, ditches, marshes etc.), different species or strain, possible inbreeding or combination of all the above mentioned factors.

The morphometric relationships between various body parts of fish can be used to assess the well being of individuals and to determine possible difference between separate unit stocks of the same species (King, 2007). The comparative study of population structure through meristic and landmark-based morphometric charateristics can be the reliable tool to highlight the situation of existing population structure of different regions. The aim of this study is to compare stock variability of G. giuris through morphometric and meristic characteristics from three different stocks such as pond stock of Mymensingh, haor stock of Kishoreganj and estuarine stock of Barisal. Stock analysis through landmark- based morphometry might give some idea as to whether there is any variation among the stocks of $G$. giuris of these three stocks. 


\section{Materials and Methods}

\section{Collection of samples}

During 1 October 2010 to 31 March 2011, 30 samples of G. giuris were collected from each of three different stocks: pond stock of Mymensingh, haor stock of Kishoreganj and estuarine stock of Barisal (Fig.1). Collected samples were placed individually into plastic bags and were kept in ice box until transportation to the laboratory under the Department of Fisheries Biology and Genetics, Bangladesh Agricultural University, Mymensingh, Bangladesh.

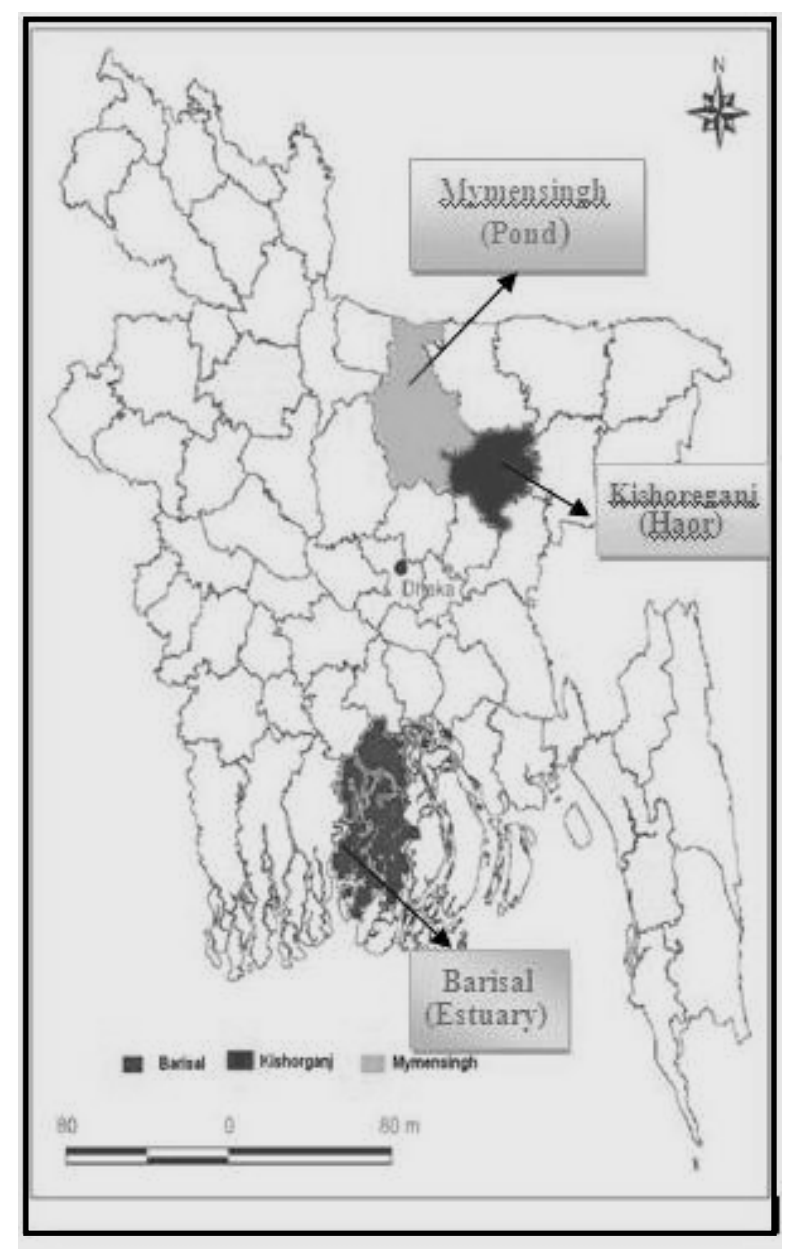

Fig. 1. Sites of sample collection

\section{Meristic counts in three different stocks of G. giuris}

Eleven meristic characters were recorded for fish of each of the three stocks, which were analyzed following the conventional method described by Hubbs and Lagler (1958). A magnifying glass was used to count the fin rays and only the principal rays were counted as separate ray. The number of vertebrae was counted by removing the muscle upon boiling fish sample.

\section{Morphometric measurements in three different stocks of G. giuris}

Thirteen general morphometric characters (Table 1 and Fig. 2) were measured from G. giuris collected from each of the three stocks following the conventional method described by Hubbs and Lagler (1958). The morphometric characters were measured with an accuracy of $0.05 \mathrm{~mm}$. 
Table 1. General morphometric characteristics used for the analysis of G. giuris stock variations

\begin{tabular}{|c|l|l|}
\hline SL & Characters & Description \\
\hline 1 & Total length $(\mathrm{TL})$ & The distance from the nose tip to the longest caudal fin ray. \\
\hline 2 & Standard length (SL) & The distance from the nose tip to the end of the vertebral column. \\
\hline 3 & Head length (HL) & The distance from the nose tip to the posterior margin of the opercula. \\
\hline 4 & Pre-orbital length (PROL) & The distance from the tip of snout to anterior margin of the eye. \\
\hline 5 & Orbital length (OL) & The diameter of the eye. \\
\hline 6 & Post-orbital length (POOL) & The distance from the posterior margin of the eye to end of operculum. \\
\hline 7 & Pre-dorsal fin length (Pre-DFL) & The distance from the snout tip to the anterior base of $1^{\text {st }}$ dorsal fin. \\
\hline 8 & Post-dorsal fin length (Post-DFL) & The distance from the posterior base of dorsal fin to the longest caudal fin ray. \\
\hline 9 & Pectoral fin base length (PcFL) & Length of the base of pectoral fin. \\
\hline 10 & Pelvic fin base length(PvFL) & Length of the base of pelvic fin. \\
\hline 11 & Anal fin base length (AFL) & Length of the base of anal fin. \\
\hline 12 & Least body depth (LBD) & Caudal peduncle length. \\
\hline 13 & Highest body depth (HBD) & $\begin{array}{l}\text { The vertical distance from the anterior part of the first dorsal fin and ventral } \\
\text { part of the body. }\end{array}$ \\
\hline
\end{tabular}

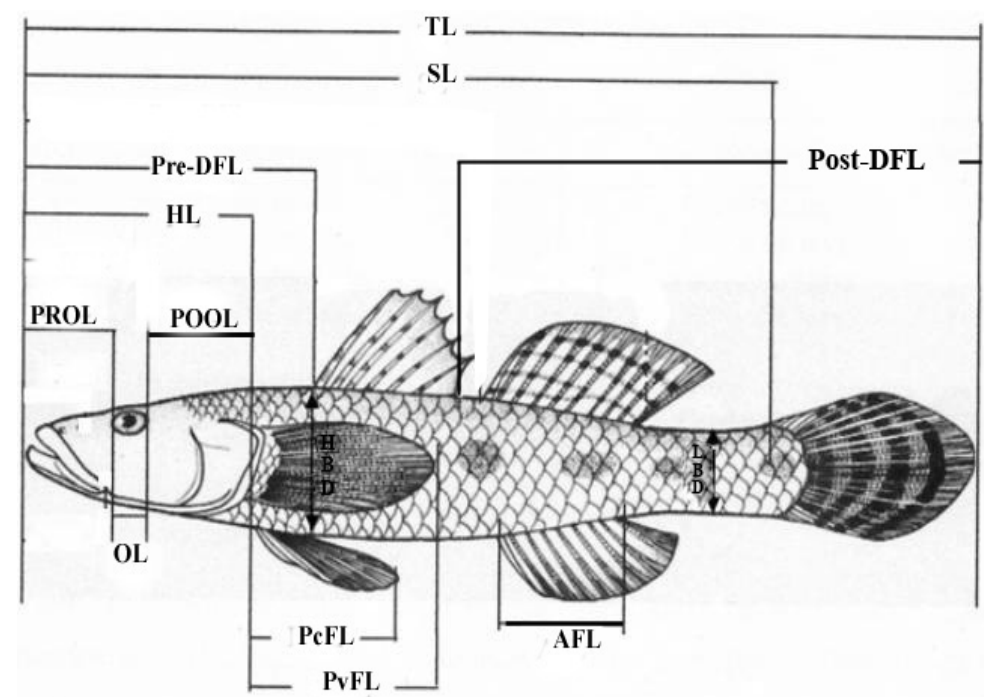

Fig. 2. Indication of the general morphometric characters on the fish body

\section{Landmark-based morphometric measurements}

Landmark morphometric data were collected using the "Truss network system". Data points were arranged in 'trusses' around the fish (Fig. 3). Twenty three landmark-based morphometric measurements (Fig. 3) were recorded. To do these twenty three different distances were defined and measured on the body by placing the fish on a graph paper and landmark points were detected with a dissecting needle. Finally, the distances on the graph paper were measured by using Vernier callipers. Prior to the analysis, it was necessary to eliminate any size effect from the data set. Variation should be attributable to body shape differences, and not related to the relative size of the fish. In the present study, there were significant linear correlations among all measured characters and the total length of the fish. Therefore, it was necessary to remove size-dependent variation for all the characters. An allometric formula given by Elliott et al. (1995) was used to remove the size effect from the data set.

$$
M_{a d j}=M\left(L_{s} / L_{o}\right)^{b}
$$

Where, M: original measurement, $M_{a d j}$ : size adjusted measurement, $L_{0}$ : total length of fish, $L_{s}$ : overall mean of standard length for all fish from all samples in each analysis. Parameter $b$ was estimated for each character from the observed data as the slope of the regression of $\log M$ on $\log L_{o}$, using all fish in all groups. 
Statistical Analysis: Meristic characters were compared using the non-parametric Kruskal-Wallis test. Univariate analysis of variance (ANOVA) were carried out to test the significance of morphological differences $(P<0.01)$ on the basis of size adjusted morphological and landmark distance data. In addition, all size adjusted morphological and landmark distance data were standardized and submitted to a discriminant function analysis (DFA). A dendrogram of populations based on the morphometric and landmark distances data were drawn by the Squared Euclidean Dissimilarity Distance. All statistical analysis were done using SPSS vers. 16 (SPSS, Chicago, IL, USA).

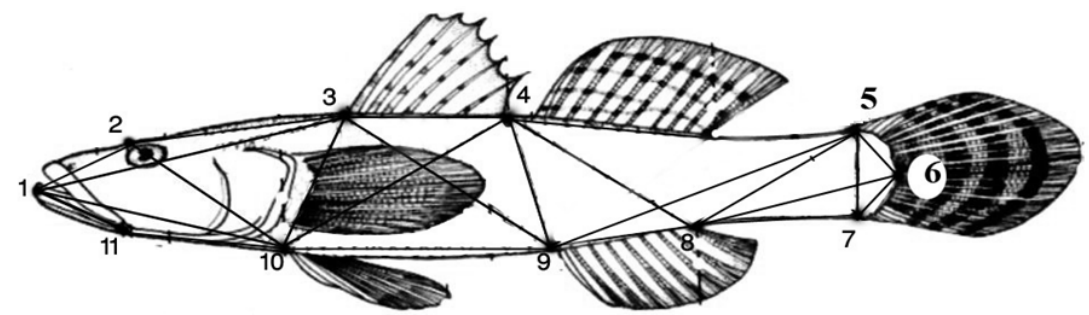

Fig. 3. Location of the 11 landmarks for constructing the truss network on fish body illustrated as black dots and morphometric distance measures between the dots as lines. Landmarks refer to (1) anterior tip of snout at upper jaw, (2) most posterior aspect of neurocranium (beginning of scaled nape), (3) origin of dorsal fin, (4) insertion of dorsal fin, (5) point at least body depth (caudal peduncle), (6) anterior attachment of dorsal membrane from caudal fin, (7) anterior attachment of ventral membrane from caudal fin, (8) insertion of anal fin, (9) origin of anal fin, (10) insertion of pelvic fin and (11) posterior most point of maxillary.

\section{Results and Discussion}

\section{Meristic counts}

Meristic counts of all samples ranged from 6 for $1^{\text {st }}$ dorsal fin rays, 9-11 (median, $m_{e}=10$ ) rays for $2^{\text {nd }}$ dorsal fin, 15-21 $\left(m_{e}=18\right)$ rays for pectoral fin, 9-11 $\left(m_{e}=10\right)$ rays for pelvic fin, 8-10 $\left(m_{e}=9\right)$ rays for anal fin,13-18 $\left(m_{e}=15\right)$ rays for caudal fin and 5 branchiostegal rays, for transverse scales on lateral line 28-32 $\left(m_{e}=29\right)$, transverse scales above lateral line 4, transverse scales below lateral line 4-5 $\left(m_{e}=4\right)$ and no. of vertebrae was 26 (Table 2). In the Kruskal Wallis $(\mathrm{H})$ test, the number of $1^{\text {st }}$ dorsal fin rays, pelvic fin rays, anal fin rays, branchiostegal rays, and no. of vertebrae, were not significantly $(P>0.05)$ different among fish from these stocks and difference occurred in other characters $\left(\mathrm{df}=2, \mathrm{D}_{2} \mathrm{FR}: \mathrm{H}=\right.$ 8.571, $\mathrm{P}<0.05$; PcFR: $\mathrm{H}=$ 46.667, $\mathrm{P}<0.05$; CFR: $\mathrm{H}=20.417$, $\mathrm{P}<0.05$; $\mathrm{TSOLL}: \mathrm{H}=8.943, \mathrm{P}<0.05$; TSALL: $\mathrm{H}=40, \mathrm{P}<0.05$ and $\mathrm{TSBLL}, \mathrm{H}=17.006, \mathrm{P}<0.05)$.

Univariate statistics (ANOVA) showed that among 11 meristic measurements, all measurements except second dorsal fin rays $\left(D_{2} F R\right)$ were significantly different $(P<0.01)$ from each other. Among 11 meristic measurements, first dorsal fin rays $\left(D_{1} F R\right)$, branchiostegal rays (BR) and no. of vertebrae cannot be computed because variables were constant (Table 2).

Table 2. Meristic counts (median) of G. giuris collected from three stocks (minimum and maximum counts in parenthesis)

\begin{tabular}{|c|c|c|c|}
\hline Meristic characters & \multicolumn{4}{|c|}{ Stocks of G. giuris } \\
\hline Parameter & $\begin{array}{c}\text { Pond of } \\
\text { Mymensingh }\end{array}$ & Haor of Kishoreganj & $\begin{array}{c}\text { Estuary of } \\
\text { Barisal }\end{array}$ \\
\hline $\mathrm{D}_{1} \mathrm{FR}$ & 6 & 6 & 6 \\
\hline $\mathrm{D}_{2} \mathrm{FR}$ & $10(11-9)$ & 10 & $10(10-9)$ \\
\hline $\mathrm{PCFR}$ & $16(17-15)$ & $20(21-20)$ & $19(21-17)$ \\
\hline PVFR & $10(11-9)$ & 10 & 10 \\
\hline AFR & $9(10-8)$ & 9 & $17(18-8)$ \\
\hline CFR & $15(16-13)$ & $16(16-14)$ & $30(31-29)$ \\
\hline TSOLL & $29(30-28)$ & $31(32-30)$ & 4 \\
\hline TSALL & 4 & 4 & $5(5-4)$ \\
\hline TSBLL & $4(5-4)$ & $5(5-4)$ & 5 \\
\hline BR & 5 & 5 & 26 \\
\hline No. of Vertebrae & 26 & 26 & \\
\hline & & & \\
\hline
\end{tabular}


In the present study, meristic counts of $G$. giuris population of pond stock ranged from 6 rays for $1^{\text {st }}$ dorsal fin, 9-11 rays for $2^{\text {nd }}$ dorsal fin, 15-17 rays for pectoral fin, 9-11 rays for pelvic fin, 8-10 rays for anal fin, 13-16 rays for caudal fin and 5 branchiostegal rays. Transverse scales on lateral line, transverse scales above lateral line, transverse scales below lateral line ranged from 28-30, 4 and 4-5 respectively. However, according to Islam and Mollah (2012) the meristic counts of G. giuris population of pond ranged from 6 rays for $1^{\text {st }}$ dorsal fin, 10-11 rays for $2^{\text {nd }}$ dorsal fin, 15-19 rays for pectoral fin, 10-12 rays for pelvic fin, 8-9 rays for anal fin, 21-28 rays for caudal fin and 5 branchiostegal rays.

Meristic counts of $G$. giuris population of haor stock ranged from 6 rays for $1^{\text {st }}$ dorsal fin, 10 rays for $2^{\text {nd }}$ dorsal fin, 20-21 rays for pectoral fin,10 rays for pelvic fin, 9 rays for anal fin, 14-16 rays for caudal fin and 5 branchiostegal rays. Transverse scales on lateral line, transverse scales above lateral line, transverse scales below lateral line ranged from 30-32, 4 and 4-5 respectively.

Meristic counts of $G$. giuris population of estuary stock ranged from 6 rays for $1^{\text {st }}$ dorsal fin, 9-10 rays for $2^{\text {nd }}$ dorsal fin, 17-21 rays for pectoral fin, 10 rays for pelvic fin, 8-9 rays for anal fin, 16-18 rays for caudal fin and 5 branchiostegal rays. Transverse scales on lateral line, transverse scales above lateral line, transverse scales below lateral line ranged from 29-31, 4 and 4-5 respectively. The meristic counts of the proposed study was more or less similar to that reported by Talwar and Jhingran (2001) and Rahman (2005) for G. giuiris. They reported that the first dorsal fin has 6, second dorsal fin has 7-9 , anal fin has 79 and the pectoral fin has 16- 21 soft rays, lateral series scales are 38- 36. However, it is dissimilar to that observed by Engin et al. (2007) in red-mouthed goby, Gobius cruentatus, in which the authors summarized the meristic characters as fins: D1 VI; D2 I/13-I/14; A I / 11+I/12; C 16-17 articulated rays, 14-15 branched; $P$ 20-21. $P$ with ends of three to four uppermost rays free from membrane. This variation is due to taxonomic difference. Although they belong to the same family i.e. Gobiidae but their genus is different. Most of the meristic counts of the present study also showed dissimilarities with that observed by Akihito and Meguro (1975) for Glossogobius aureus. They recorded second dorsal mostly I, 9; anal mostly I, 8; pectoral 16-21; scale in a longitudinal series 29-34; scale in a transverse series 8-12; predorsal scale 19-29. Anal and pelvic fins not mottled, caudal fin mottled with dark spots in G. aureus. This is also true for $G$. giuris.

Among the 11 meristic counts the first dorsal fin rays $\left(D_{1} F R\right)$, transverse scale above lateral line (TSALL), branchiostegal rays and number of vertebrae were same among fishes from these stocks (Table 2). However, in case of pectoral fin rays (PcFL) and transverse scale on lateral line (TSOLL) the haor stock of Kishoreganj was significantly higher than other stocks (pond stock of Mymensingh and estuary stock of Barisal).

Table 3. Univariate statistics (ANOVA) testing for differences among stocks using meristic measurements

\begin{tabular}{|c|c|c|c|}
\hline Meristic measurements & Wilks' Lambda & F & Sig. \\
\hline $\mathrm{D}_{1} \mathrm{FR}$ & - & - & \\
\hline $\mathrm{D}_{2} \mathrm{FR}$ & 0.997 & 0.092 & 0.912 \\
\hline $\mathrm{PCFR}$ & 0.249 & 102.459 & $0.000^{*}$ \\
\hline $\mathrm{PVFR}$ & .723 & 13.036 & $0.000^{*}$ \\
\hline $\mathrm{AFR}$ & 0.837 & 6.621 & $0.002^{\star}$ \\
\hline $\mathrm{CFR}$ & 0.305 & 77.522 & $0.000^{*}$ \\
\hline TSOLL & 0.671 & 16.695 & $0.000^{*}$ \\
\hline TSALL & 0.404 & 50.115 & $0.000^{*}$ \\
\hline TSBLL & 0.626 & 20.309 & $0.000^{*}$ \\
\hline BR & - & - & - \\
\hline No. of Vertebrae & - & - & - \\
\hline
\end{tabular}

${ }^{*} \mathrm{P}<0.01$ 


\section{Morphometric and landmark measurements}

Univariate statistics (ANOVA) showed that 13 size adjusted general morphometric measurements were significantly different $\left({ }^{*} \mathrm{P}<0.01\right)$ from each other (Table 4). Similarly, all 23 size adjusted landmark-based morphometric measurements were significantly different $\left({ }^{*} \mathrm{P}<0.01\right)$ from each other (Table 5).

Table 4. Univariate statistics (ANOVA) testing for differences among stocks using size adjusted general morphometric distances

\begin{tabular}{|c|c|c|c|}
\hline General morphometric measurements & Wilks' Lambda & F & Sig. \\
\hline SL & 0.008 & 4344.271 & $0.000^{*}$ \\
\hline HL & 0.019 & 1879.483 & $0.000^{*}$ \\
\hline EL & 0.645 & 19.560 & $0.000^{*}$ \\
\hline Pre-OL & 0.088 & 367.282 & $0.000^{*}$ \\
\hline Post-OL & 0.019 & 1831.575 & $0.000^{*}$ \\
\hline Pre-DFL & 0.024 & 1474.371 & $0.000^{*}$ \\
\hline Post-DFL & 0.018 & 1992.033 & $0.000^{*}$ \\
\hline LBD & 0.137 & 223.465 & $0.000^{*}$ \\
\hline HBD & 0.107 & 296.887 & $0.000^{*}$ \\
\hline PCFL & 0.133 & 231.041 & $0.000^{*}$ \\
\hline PVFL & 0.129 & 240.086 & $0.000^{*}$ \\
\hline AFL & 0.038 & 889.268 & $0.000^{*}$ \\
\hline
\end{tabular}

*P $<0.01$

Table 5. Univariate statistics (ANOVA) testing for differences among stocks using size adjusted landmark distances

\begin{tabular}{|c|c|c|c|}
\hline Landmark distances & Wilks' Lambda & $F$ & Sig. \\
\hline $1-2$ & 0.109 & 290.317 & $0.000^{*}$ \\
\hline $1-3$ & 0.011 & 3101.188 & $0.000^{*}$ \\
\hline $1-10$ & 0.026 & 1309.021 & $0.000^{*}$ \\
\hline $1-11$ & 0.204 & 138.584 & $0.000^{*}$ \\
\hline $2-3$ & 0.018 & 1978.755 & $0.000^{*}$ \\
\hline $2-10$ & 0.027 & 1264.249 & $0.000^{*}$ \\
\hline $3-4$ & 0.055 & 610.171 & $0.000^{*}$ \\
\hline $3-9$ & 0.038 & 898.799 & $0.000^{*}$ \\
\hline $3-10$ & 0.066 & 503.440 & $0.000^{*}$ \\
\hline $4-5$ & 0.082 & 400.035 & $0.000^{*}$ \\
\hline $4-8$ & 0.048 & 697.238 & $0.000^{*}$ \\
\hline $4-9$ & 0.069 & 479.585 & $0.000^{*}$ \\
\hline $4-10$ & 0.051 & 657.617 & $0.000^{*}$ \\
\hline $5-6$ & 0.118 & 266.092 & $0.000^{*}$ \\
\hline $5-7$ & 0.037 & 913.105 & $0.000^{*}$ \\
\hline $5-8$ & 0.127 & 244.851 & $0.000^{*}$ \\
\hline $5-9$ & 0.043 & 786.584 & $0.000^{*}$ \\
\hline $6-7$ & 0.073 & 452.768 & $0.000^{*}$ \\
\hline $6-8$ & 0.049 & 684.389 & $0.000^{*}$ \\
\hline $7-8$ & 0.080 & 408.344 & $0.000^{*}$ \\
\hline $8-9$ & 0.040 & 841.835 & $0.000^{*}$ \\
\hline $9-10$ & 0.056 & 597.631 & $0.000^{*}$ \\
\hline $10-11$ & 0.044 & 776.065 & $0.000^{*}$ \\
\hline & & & \\
\hline
\end{tabular}

${ }^{\star} P<0.01$ 
Efficiency of the allometric formula in removing the size effect from the data was justified by using correlation between total length and adjusted characters. That is why total length was excluded first and not transformed because using this parameter as standard all other parameters were standardized. All the twelve transformed morphometric measurements as well as 23 landmark distances were found highly correlated with total length. Islam and Mollah (2012) observed the similar results.

Prior to discriminant analysis (DA), discriminant function scores 1 and 2 were determined on the basis of software process using size adjusted general morphometric and landmark distances and plotted in the discriminant space. In discriminant space, pond stock of Mymensingh was separated from other stocks (Fig. 4). This suggested that pond stock was morphologically dissimilar to other stocks (haor of Kishoreganj and estuary of Barisal) of G. giuris. On the other hand, haor stock of Kishoreganj and estuary stock of Barisal showed very close relationship. This suggested that the three stocks are morphologically fragmented or divergent and more or less isolated from each other. Discriminant function analysis produced two discriminant function (DF1 and DF2) for both morphometric and landmark measurements.

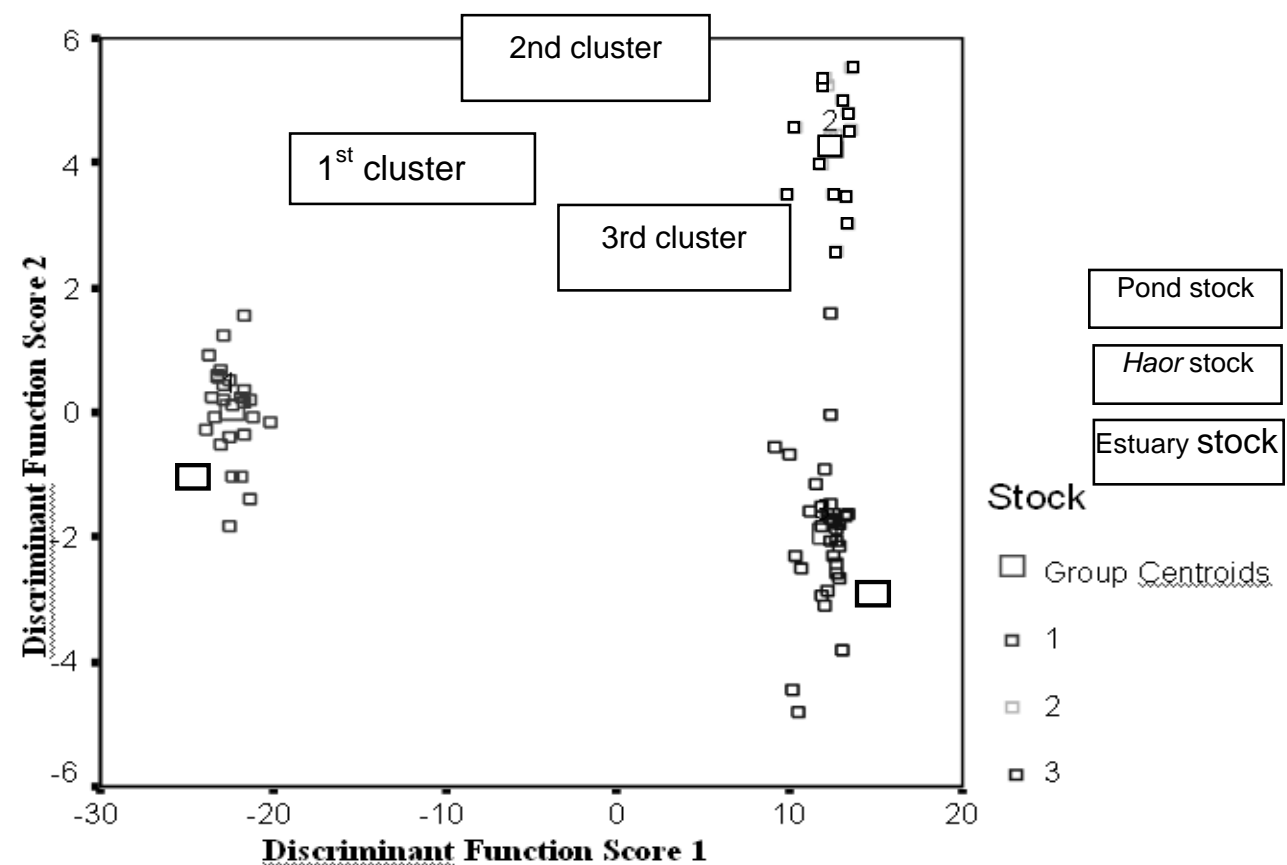

Fig. 4. Sample centroids of discriminant function scores based on size adjusted general morphometric and landmark distances. Group centroids refer to-1. Pond stock, 2. Haor stock and 3. Estuary stock

For morphometric and landmark measurements the first DF accounted for $98.7 \%$ and $76.0 \%$ and the second DF accounted for $1.3 \%$ and $24.0 \%$ respectively of among group variability, explaining $100 \%$ of total among group variability.

Pooled within groups correlation between discriminant variables and DFs revealed that among the 13 morphometric measurements: pre-dorsal fin length (Pre-DFL), head length (HL), standard length (SL), post orbital length (Post-OL), least body depth (LBD) and highest body depth (HBD) contributed to the first DF and the rest six measurements- post dorsal fin length (Post-DFL), anal fin length (AFL), preorbital length (Pre-OL), pectoral fin length (PcFL), pelvic fin length (PvFL), and orbital length (OL) contributed to the second DF (Table 6). 
Table 6. Pooled within-groups correlations between discriminating variables and standardized canonical discriminant functions in case of general morphometric characteristics

\begin{tabular}{|l|c|c|}
\hline & DF1 & DF2 \\
\hline Pre-DFL & $0.604\left(^{*}\right)$ & 0.384 \\
\hline HL(a) & $0.539\left(^{*}\right)$ & 0.485 \\
\hline SL(a) & $0.528\left(^{*}\right)$ & 0.488 \\
\hline Post-OL(a) & $0.518\left(^{*}\right)$ & 0.487 \\
\hline LBD(a) & $0.377\left(^{*}\right)$ & 0.357 \\
\hline HBD & $0.353\left(^{*}\right)$ & 0.230 \\
\hline Post-DFL & 0.440 & $0.587\left(^{*}\right.$ \\
\hline AFL(a) & 0.481 & $0.526\left(^{*}\right)$ \\
\hline Pre-OL(a) & 0.472 & $0.501\left(^{*}\right)$ \\
\hline PcFL(a) & 0.426 & $0.473\left(^{*}\right)$ \\
\hline PvFL(a) & 0.352 & $0.443\left(^{*}\right)$ \\
\hline OL(a) & 0.131 & $0.205\left(^{*}\right)$ \\
\hline
\end{tabular}

Variables ordered by absolute size of correlation within function.

* Largest absolute correlation between each variable and any discriminant function.

In case of landmark measurements (truss measurements) among the 23 measurements -1 to 11 and 4 to 9 dominantly contributed to the first DF (DF1) and the rest 21 measurements contributed to the second DF (Table 7).

Table 7. Pooled within-groups correlations between discriminating variables and standardized canonical discriminant functions in case of landmark distances

\begin{tabular}{|c|c|c|}
\hline & DF1 & DF 2 \\
\hline 1 to11 & $0.482\left(^{\star}\right)$ & 0.218 \\
\hline 4 to 9 & $0.185\left(^{*}\right)$ & 0.159 \\
\hline 9 to 10 & 0.356 & $0.570\left(^{*}\right)$ \\
\hline 10 to 11 & 0.250 & $0.535\left(^{*}\right)$ \\
\hline 2 to 3 & 0.283 & $0.533(*)$ \\
\hline 1 to 3 & 0.270 & $0.530(*)$ \\
\hline 7 to 8 & 0.332 & $0.491(*)$ \\
\hline 4 to 10 & 0.321 & $0.483\left({ }^{*}\right)$ \\
\hline 1 to 10 & 0.251 & $0.482\left(^{*}\right)$ \\
\hline 2 to 10 & 0.246 & $0.471\left({ }^{*}\right)$ \\
\hline 5 to 6 & 0.315 & $0.468\left(^{*}\right)$ \\
\hline 3 to 9 & 0.286 & $0.467\left(^{*}\right)$ \\
\hline 3 to 4 & 0.305 & $0.463\left({ }^{*}\right)$ \\
\hline 3 to 10 & 0.280 & $0.445\left(^{\star}\right)$ \\
\hline 1 to 2 & 0.235 & $0.427\left(^{*}\right)$ \\
\hline 5 to 7 & 0.337 & $0.426\left(^{*}\right)$ \\
\hline 5 to 9 & 0.254 & $0.407\left(^{*}\right)$ \\
\hline 8 to 9 & 0.211 & $0.395(*)$ \\
\hline 6 to 8 & 0.331 & $0.391\left(^{\star}\right)$ \\
\hline 4 to 8 & 0.243 & $0.371\left(^{\star}\right)$ \\
\hline 6 to 7 & 0.262 & $0.355(*)$ \\
\hline 4 to 5 & 0.278 & $0.346\left({ }^{*}\right)$ \\
\hline 5 to 8 & 0.123 & $0.314\left(^{*}\right)$ \\
\hline
\end{tabular}

Variables ordered by absolute size of correlation within function.

*Largest absolute correlation between each variable and any discriminant function.

A dendrogram based on the hierarchial cluster analysis using size adjusted general morphometric and landmark measurements for G. giuris are shown in Fig. 5. The dendrogram formed two main clusterspond stock in one cluster and other two stocks (haor and estuary) remained in another cluster. It indicates that pond stock was separated. The second cluster of dendrogram explained that haor and estuary stocks had very close relationship. 


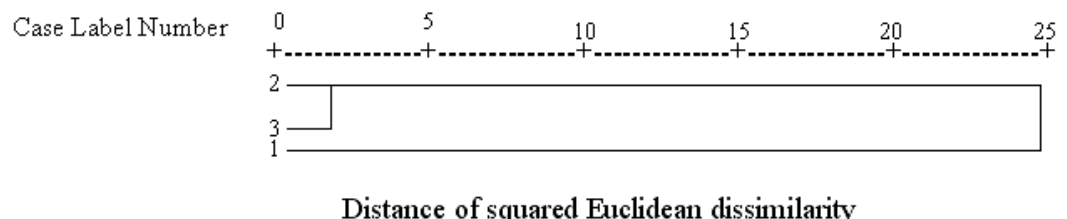

Fig. 5. Dendrogram based on average linkage (between groups) of pond (1), haor (2) and estuary stock (3) of $G$. giuris

The morphometric differences among three stocks are expected because they are geographically separated and may have originated from different ancestors. Therefore, it is not unlikely that environmental variations exist in these three stocks. Hence the difference between the pond stock with those of haor and estuary may have been due to environmental as well as genetic variations. Fish are very sensitive to environmental changes and quickly adapt themselves by changing necessary morphometrics (Hossain et al., 2010). In general, fish demonstrate greater variances in morphological traits both within and between populations than other vertebrates, and are more susceptible to environmentally induced morphological variations (Allendrof et al., 1987; Wimberger, 1992).

However, the differences in morphology of fish due to the environmental difference may not be found in gross morphometric characters. Therefore, truss network measurements (Landmark distance) were employed in this experiment. Truss network system is a powerful tool for identifying phenotypic traits of fish species (Turan et al., 2004b). An unbiased network of morphometric measurements over a 2 dimensional outline of a fish removes the need to find the types of characters and optimal number of characters for stock separation and provides information over the entire fish form (Turan et al.,2004b). The truss network system can be used effectively to distinguish among different stocks, subspecies, groups etc. In this case, more significant differences were expected because of three different stocks. The difference between the pond stock and haor stock as well as estuary stock may be due to environmental condition.

Present study was not designed to investigate the actual cause due to which morphological variation occurs in different stocks of same species and to determine whether the morphological variations are environmentally induced or due to genetic factors or both. Investigation to this regard may be initiated on the basis of the present findings.

\section{Acknowledgements}

The authors take the privilege to acknowledge BAS (Bangladesh Academy of Science) authorities for providing financial assistance.

\section{References}

Akihito, P. and Meguro, K. 1975. Description of a new Gobiid Fish, Glossogobius aureus, with notes on related species of the genus. Japan J. of Ichthyo., 22 (3):127-142.

Allendorf, F.W., Ryman, N. and Utter, F. 1987. Genetics and fishery management: past, present and future in population genetics and fisheries management. Seattle, WA \& London: University of Washington press. 1-20 pp.

Bhuiyan, A.L. 1964. The fishes of Dacca. Asiatic Soc. Pak. Dacca. Pub. No 13, 148 p.

Elliott N.G., Haskard, K. and Koslow, J.A. 1995. Morphometric analysis of orange roughy (Hoplostethus atlanticus) off the continental slope of southern Australia. J. of Fish Biology, 46: 202-220.

Engin, S., Turan, D. and KOVACIC, M. 2007. First record of the red-mouthed goby, Gobius cruentatus (Gobiidae), in the Black Sea. Cybium, 31(1): 87-88.

Hoese, D.F. 1986. Gobidae. In Smith's Sea Fishes. Springer-Verlag, Berlin, 774-787.

Hoese, D.F. 2008. Radiation of Glossogobius giuris in freshwaters of the Indo-West Pacific. Proceedings of International Symposium on Systematics and Diversity of Fishes. $11 \mathrm{p}$. 
Hossain, M.A.R., Nahiduzzaman, M., Saha, D., Khanam, M.U.H. and Alam, M.S. 2010. Landmark-based Morphometric and Meristic Variations of the Endangered Carp, Kalibaus Labeo calbasu, from Stocks of Two Isolated Rivers, the Jamuna and Halda, and a Hatchery. Zoological Studies, 49(4): 556-563.

Hubbs, C.L. and Lagler, K.F. 1958. Fish of the great lakes region. Second Ed. Univ. Mich. Press. Ann Arbor. 213 p.

Islam, M.N. 2002. Cannibalism of fresh water gobi, Glossogobius giuris (Hamilton) in relation to its size, sex and season from the river Padma. University J. of zool. Rajshahi University, 21: 63-64.

Islam, M.N. and Joadder, M.A.R. 2005. Seasonal variation of the proximate composition of freshwater gobi, G. giuris (Hamilton) from the river Padma. Pakistan J. of Biological Sci., 8(4): 532-536.

Islam, M.R. and Mollah, M.F.A. 2012. Morphological observation and PG-induced breeding of Glossogobius giuris (Hamilton 1822). J. Science and Technology. 11.

King, M. 2007. Fisheries biology assessment and management. Second Edition. Blackwell Scientific publications, Oxford, 1-381.

Rahman, A.K.M. 1989. Freshwater Fishes of Bangladesh. The Zoological Society of Bangladesh, Department of Zoology, University of Dhaka, Bangladesh, 168-169.

Rahman, A.K.M. 2005. Freshwater Fishes of Bangladesh. The Zoological Society of Bangladesh, department of Zoology, University of Dhaka, Bangladesh, 307-308.

Srivastava, G.J. 1968. Fish of Eastern Uttar Pradesh. First Ed. Published by Vishwavidyalaya prakashan, Varanasi (India), 163 pp.

Talwar, P.K. and Jhingran, A.G. 2001. Inland fishes of India and adjacent countries. Oxford and IBH pub. Co. Pvt. Ltd. New Delhi. 2: 936.

Turan, C. D., Erguden, M., Gurlek, N., Basusta and Turan, F. 2004b. Morphometric structuring of the anchovy (Engraulis encrasicolus L.) in the Black, Aegean and northeastern Mediterranean seas. Turkish J. of Vetenary and Animal Sci., 28: 865-871.

Wimberger, P.H. 1992. Plasticity of fish body shape the effects of diet, development, family and age in two species of Geophagus (Pisces, Cichlidae). Biological. J. of Linnology Soc., 45: 197-218. 